\title{
Molecularly-imprinted polymers as synythetic mimics of bioreceptors. 2. Applications in modern biotechnology
}

\section{T.A.Sergeyeva}

Institute of Molecular Biology and Genetics, 150 Zabolotnogo str., Kiev, Ukraine, 03680

t_sergeyeva@yahoo.co.uk

\begin{abstract}
The review is devoted to the analysis of publications on the synthesis of artificial mimics of biological receptors as well as their application in biotechnology. The special attention is paid to such areas of biotechnology: sensor technology, solid-phase extraction, pseudoimmunoassay, and chromatography.
\end{abstract}

Keywords: molecular imprinting, molecularly imprinted po-lymer, polymers-biomimics.

In the first review [1] the main principles of synthesis of bioreceptor mimics by the method of molecular imprinting were described. The main groups of molecularly imprinted polymers that are being used in modern biotechnology were reviewed, while the main attention was focused on polymers-biomimics obtained by the method of non-covalent molecular imprinting. Molecularly-imprinted polymers (MIPs) form the biggest group of synthetic receptors, which is the most promising in terms of applications and commercialization. The present review is devoted to application of molecularly imprinted polymers in modern biotechnology, i.e. sensor technology, solid-phase extraction, pseudoimmunoassay, and chromatography.

Chromatography. Chromatography was historically the first method proposed for the investigation of MIP recognition ability, which remains prevalent to date. MIPs are being widely used as a stationary phase for high-performance liquid chromatography (HPLC). HPLC is also the most investigated area in their practical application. That is

(C) Institute of Molecular Biology and Genetics NAS of Ukraine, 2009 associated with the possibility of synthesis of a stationary phase with the predicted selectivity either towards individual substance or a group of structurally-similar substances (depending on research or technological needs), provided by the technique of molecular imprinting. A number of publications were devoted to application of MIPs as a stationary phase in chromatographic identification of pharmaceuticals [2-8], drugs [9], amino acids [10-13], sugars [14-16], pesticides [17-20], antioxidants [21], peptides [22-25], phenols [26, 27], etc.

Liquid chromatography is an effective method of MIPs' properties investigation. However, their application in liquid chromatography has a number of essential drawbacks. First of all, it is broadening of chromatographic peaks associated with difficulties of mass transfer through the highly-cross-linked polymer as well as occurrence in MIPs binding sites with different affinity to the template molecule. Population of selective sites in MIPs consists of a certain number of sites with high affinity, while the major part of the sites is characterized with significantly lower affinity. Highly affine sites are being saturated quickly, while the template molecules inside are being strongly 
retained. Therefore, chromatographic separation of structurally-similar substances takes place mainly under participation of less affine sites, which results in poor separation (broadening or overlapping of chromatographic peaks). Another reason for peaks broadening is application of polymeric particles of irregular shape (20-25 $\mu \mathrm{m}$ diameter), obtained by grinding of synthesized polymeric monoliths, as a stationary phase for chromatography.

Most of publications in the area of MIP-based chromatography describe application of traditional acrylate or methacrylate polymers obtained by block-copolymerization of methacrylic acid and ethyleneglycoldimethacrylate. Better results in chromatographic separation give MIPs obtained by suspension polymerization [8, 28, 29], multi-step swelling polymerization [30-34], surface modification of silica [35], and porous MIP monoliths [36-43]. These areas are the most promising in MIP-based chromatography.

Solid-phase extraction (SPE). Application of MIPs in analytical chemistry, biotechnology, medicine, food chemistry, and environmental monitoring attracts significant attention of analysts due to necessity of development new effective methods for sample pre-concentration and purification [44, 45]. SPE is widely used for extraction of analytes and removal of interferents from complex samples, substitution of aqueous solvents for organic ones, storage and transportation of samples.

Significant interest of analysts in solid-phase extraction is associated with necessity of pre-treatment of real samples before their analysis by both traditional instrumental and biosensor methods. This procedure takes up to $90 \%$ of the total time of analysis and forms $85 \%$ of its price. It is also remains the main source of mistakes in the analytical identification of toxic molecules. There is a necessity in development of new SPE approaches, which can provide selective pre-concentration of samples of toxic molecules and possibility of their analysis in extremely low (approximately $10^{-9} \mathrm{M}$ ) concentrations. Therefore, SPE is the most promising area of MIPs' practical application and commercialization. That is confirmed by the sharp increase in the number of publications on the MIP-based pre-treatment of real samples, which significantly facilitates their further analysis by traditional analytical methods.

MIPs have a number of advantages as compared to traditional SPE adsorbents. The main problem in application of traditional adsorbents is their insufficient selectivity, which results in high levels of non-specific adsorption of components of real samples during analysis. That causes high "noise" levels and high non-specific peaks in further chromatography, decreasing effectiveness of the analysis. MIPs similarly to highly-specific immunoadsorbents provide selective adsorption of either template molecules or a group of substances with similar structure. Therefore, one can get extracts free from the interferents, while the procedure itself includes only one stage even in the case of real samples. As compared to immunoadsorbents, the methods of MIP synthesis are simple, reproducible, and inexpensive, moreover they are not time-consuming. At the same time, MIPs are characterized with significantly higher adsorption capability and storage stability [46, 47]. Stability of MIPs in the presence of acids, alkalis, and organic solvents gives a possibility of MIP-based columns/cartridges application on-line in HPLC.

For the first time MIPs were used in solid-phase extraction for pentamidine determination in urine [48]. Now they are widely used for purification and pre-concentration of analytes from real samples in medicine [49-56], food industry [57-66], and environmental monitoring [67-77]. This results in the significant (10-1000 times) decrease in detection limits of corresponding analytes.

The major part of MIPs that are being used in SPE are synthesized according to the method of non-covalent molecular imprinting by bulk-polymerization $[48,49,57,59,61,66,69-71,74$, 77, 78], precipitation [79], suspension [80], one/two/multistep swelling polymerization [81-83]. In most cases, application of traditional acrylate/methacrylate monomers is proposed, while MIPs are copolymers of methacrylic acid and ethyleneglycoldimethacrylate obtained by the method of bulk polymerization.

Bulk-polymerization is the easiest and the most popular method out the above-mentioned ones. It assumes grinding of the synthesized polymer 
monoliths and fractionating obtained polymeric particles by size (the fraction $25-50 \mu \mathrm{m}$ is usually used). The disadvantage of the method is loss of $30-40 \%$ of the polymer during the procedure, while irregular shape of particles in the case of their on-line combination with HPLC results in appearance of broad asymmetric peaks. If these two procedures are carried out successively (off line), this disadvantage is not critical. The methods of precipitation, suspension, one/multistep swelling polymerization are characterized with less significant loss of the material. However, they are much more difficult and time-consuming as compared to the method of bulk polymerization.

Application of close structural analogues of a template molecule in MIP synthesis is an interesting approach in SPE [82, 84-90]. On the one hand, it eliminates problems associated with the template leaching during extraction, which might affect accuracy of the further analysis. From the other hand, it decreases the price of molecularly imprinted polymer, which is important if the template is expensive. This approach is also effective if the template is toxic (bacterial toxins, mycotoxins, substances affecting nervous system, explosives, etc.). Watabe et al. and Kubo et al. [84, 85] demonstrated a possibility of MIP synthesis for the selective adsorption of bisphenol A by the method of two-step swelling polymerization. They used $p$-tretbutylphenol as a pseudotemplate. Application of the MIP in SPE combined with HPLC gave a possibility of bisphenol A detection in extremely low concentrations in river water samples. A similar approach was used for the synthesis of sameridine-selective

and

D,L-tetrahydropalmatine-selective [86] polymers as well as polymers selective towards harmane, harmaline, and harmine [87], S-naproxen and ibuprofen [88], phenobarbital [89], phenylurea herbicides [92], atrazine [93], zearalenone [94], domoic acid [82], ochratoxin A [95], and antivirus drug abacavir [96].

The most widespread SPE format is glass or polypropylene cartridges filled with the adsorbent placed between two porous frits from polyethylene/Teflon/ stainless steel. The main disadvantage of this format is a small diameter of cartridges, which results in a relatively small productivity. That is especially important in the case of large-volume probes. Moreover, there is a problem of SPE combination with instrumental analytical methods (gas chromatography-mass spectrometry, HPLC, HPLC-MS). From this point of view, the method of microextraction proposed Koster et al. [97] is very promising. In this case analyte extraction takes place on the surface of silicon dioxide fibrils, modified with a thin MIP layer. The idea of Koster was extended by the other authors [98], who developed the method of solid-phase microextraction of triazine herbicides combined with HPLC. The authors demonstrated a possibility of prometryn, propazine, atrazine, symetryn, ametryn, tertbutylazine, and tertbutryn in the range $0.012-0.09 \mu \mathrm{g} / \mathrm{l}$. The synthesis of the ochratoxin A-imprinted polymer through polypyrrole electropolymerization on the surface of stainless steel frits is proposed in [99]. The modified frits were used on-line in HPLC.

One of the most promising approaches in the area of MIP-SPE application is synthesis of MIP monoliths, obtained either by bulk polymerization [43, 86, 100-103] or grafting polymerization [104]. Porous structure of these polymeric adsorbents can provide effective mass-transfer, high productivity, and effective adsorption of the analyte molecules. Application of porous MIP monoliths eliminates main drawbacks of the analysis based on MIP particles (long preparation times and significant losses of the selective binding sites during preparation of the polymer). However, absence of the universal procedure of the synthesis of highly-productive monoliths demands optimization of the synthetic procedure for the each new template.

From this point of view, application of porous MIP membranes, obtained either by in situ polymerization [105-116] or grafting polymerization of a thin MIP layer on commercially-available porous microfiltration membranes [117-120] in SPE proposed for the first time by our group is to be considered. These methods are universal and quite simple. They don't require optimization in the case of use of different template molecules. Moreover, in contrast to polymeric particles, no loss of the polymeric material takes place during the membranes' synthesis. The MIP membranes 
are highly productive and provide good mass transfer. An additional advantage of the MIP membranes is that they can be combined on-line with instrumental analytical methods. Due to the absence of mechanical deformation, the synthesized MIP membranes demonstrate the highest documented adsorption capabilities towards template molecules $(60-160 \mu \mathrm{M} / \mathrm{g}$ polymer). Adsorption capability of the MIP adsorbent based on polymeric particles is significantly lower as compared to the MIP membranes and according to data presented by different authors varies from $1-40 \mu \mathrm{M} / \mathrm{g}$ polymer.

Immunosorbent pseudoimmunoassay based on molecularly imprinted polymers. Unique properties of antibodies (capability of selective recognition of corresponding antigens) stimulated development of radioimmunoassay and enzyme-linked immunosorbent assays, which became routine methods for laboratory detection of various analytes [121-124]. Since molecularly imprinted polymers as well as antibodies capable of selective recognition of corresponding template molecules, they can be used in immunoassays as a highly-stable alternative to natural receptors. Similarly to immunoassay, this approach is called "molecularly imprinted sorbent assay" (MISA).

Application of MIPs in immunoassays was proposed for the first time by Mosbach et al. [125], who developed a procedure of competitive radiopseudoimmunoassay for detection of theophiline and diazepam. Theophiline and diazepam extracted form plasma samples by an organic solvent were analyzed. MIP particles were separated by centrifugation and concentration of the radioactive analyte in the supernatant was determined. The authors demonstrated the possibility of theophiline and diazepam detection within the range $14-224 \mu \mathrm{M}$, which is comparable to sensitivity of immunoanalysis for these substances. This approach was further developed and MIP-based immunoassays for morphine and enkephaline were developed [126]. The special feature of these polymers is their capability of analyte recognition in aqueous media. Affinity and selectivity of the polymers in aqueous environment were worse as compared to organic solvents. However, sensitivity and selectivity of the MIP-based assay were similar to those of immunoassay. Using these principles a number of pseudoimmunoassays for (S)-theophiline [127], (S)-propanolol [128], atrazine [129, 130], estradiol [131], corticosterone, cortisole [132], Я-lactam antibiotics [133, 134], 2,4-D [135-137] etc. were developed. Importantly, MIPs can be obtained not only for low-molecular weight substances. From this, point of view the papers $[138,139]$ are of great interest. They describe data on visualization of radioactively-labeled proteins (albumin, lactalbumin, lisozyme, ribonuclease, and streptavidine). Protein-selective molecularly imprinted sites were obtained by plasma-polymerization of $\mathrm{C}_{3} \mathrm{~F}_{6}$, deposited on mica surface with the previously adsorbed proteins covered by a disaccharide layer. Removal of mica and extraction of the template molecules resulted in formation of imprints in the polymer that were capable of selective adsorption of radioactive analogues of the template molecules.

Enzyme labels are successfully used in MISA along with radioactive labels. Tobacco and horseradish peroxidases were used for development of MISA for 2,4-D, atrazine, epinephrine, and phenylephedrine detection [140-145]. Detection limits of the above-mentioned analytes were in submicromolar range and were similar to those of ELISA. In many cases selectivity of MIP-based immunosorbent assays was higher as compared to antibody-based assays [128, 129].

The most promising MISA variants are presented in $[143,144,146]$. The authors describe modification of the surface of standard 96-well ELISA plates by a thin polymer layer using the method of grafting polymerization. That gives a possibility to avoid technological problems associated with the use of polymeric particles (washing and separation of the particles by centrifugation) and provides rapid screening of samples. Piletsky et al. developed a test-system for epinephrine and ephedrine detection [143]. The method of modification of polystyrene ELISA plates by a thin layer of molecularly-imprinted poly-3-aminophenylboronic acid was proposed. 3-Aminophenylboronic acid was used as a functional monomer capable of formation molecular complexes with the template due to formation of electrostatic, hydrophobic, and reversible covalent bonds. At the same time, 3-aminophenylboronic acid was used as a cross-linker, which was responsible for fixation of the 
template-functional monomer complexes in the polymeric network. Sensitivity of the developed test-system comprised 1-100 $\mu \mathrm{M}$. Unfortunately the described polymers could not be used for the analysis of biological samples, since presence of serum proteins and sugars resulted in a significant decrease in the sensitivity. The application of the developed test-systems was limited to non-biological samples only.

Similar approach was used for the development of a pseudoimmuno-test-system for atrazine detection $[144,146]$. The authors describe competitive analysis, based on competition of atrazine and its analogue (5-(4,6-dichlorotriazinyl)aminofluoresceine)

for atrazine-selective MIP sites. The test-systems for low-molecular weight substances (atrazine, epinephrine, and ephedrine) as well as proteins (microperoxidase, lactoperoxidase, horseradish peroxidase, and cytochrome C) were developed. In this case, molecularly imprinted polyaniline grafted to the polystyrene surface woks as an antibody mimic. The assay does not require application of additional dyes for visualization of the bound molecules.

Most of the existing variants of MISA based on application of either radioactive or enzyme labels are heterogeneous assays, which require additional stage of bound and free analytes. An interesting approach in MISA is its homogeneous variant based on fluorescent labels. This approach is based on application of fluorescent functional monomers for the polymer synthesis, while binding of template molecules with the analyte-selective site changes the fluorescence intensity. These changes are proportional to the analyte concentration in the analyzed sample. From this point of view, the method of covalent imprinting based on reversible covalent interactions between the template and functional monomers was found to be the most effective [147, 148]. Application of a non-covalent approach for the development of fluorescent homogeneous pseudoimmunoanalysis was described in [149-152]. The authors prove formation of electrostatic interactions and hydrogen bonds between fluorescent functional monomers and templates. The main drawback of this approach is high fluorescent background, which limits sensitivity of the analysis.

It should be noted that antibodies are the widespread and effective reagents for immunoanalysis.
However, MIPs can provide a promising alternative. Despite the fact that recognition of analytes by molecularly imprinted polymers in aqueous environment in many cases needs further improvement, MIP-based analysis in organic solvents is more sensitive as compared to the antibody-based one. That significantly broadens possibilities of detection of nonimmunogenic substances.

Molecularly imprinted polymers in sensor technology. It is widely recognized that biosensor methods are the most effective methods of modern analytical biotechnology. They are characterized by high sensitivity and selectivity, short time of analysis, and low cost. MIPs can be used as substitutes of antibodies in pseudoimmunoanalysis as well as in sensor technology. The MIP-based sensors are similar to immunosensors or enzyme sensors. MIPs are used as sensor selective elements, which is responsible for analyte recognition. At the same time, MIP is in the close contact with a physical transducer, which is responsible for transformation of the signal occurring after the analyte binding into electrochemical, thermal or optical one. This signal is proportional to the analyte concentration in the analyzed sample.

Similarly to immunosensor devices, the event of the analyte binding in MIP-based sensors is not accompanied with appearance of electroactive products (protons, electrons, etc.). The sensors for direct detection of MIP-analyte binding are based on changes in properties of the immobilized MIP (charge, weight, capacity) after the interaction with the corresponding analyte. Despite the fact, that these changes are very insignificant, a number of sensors based on detection MIP-analyte binding using mass-selective detectors (quartz-crystal microbalance [153-162] and Love wave-based sensors $[154,163])$ were described. These transducers were used for development of sensors for glucose based on electropolymerized poly(o-phenylenediamine [153], sensors for organic solvents based on polyurethanes [155, 157], sensors for (S)-propanolol [158] and caffeine [161] based on traditional acrylate polymers). Since weight of the immobilized MIP after its interaction with the corresponding analyte changes insignificantly, sensitivity of these devises is relatively low. The analytes can be detected in micro- milimolar range. 
Among the publications devoted to direct detection of a MIP-analyte binding event, papers on development of capacitive and potentiometric sensors based on electrodes/field effect transistors modified with a thin MIP layer grafted to the transducer surface are of great importance [117, 146, 164-168]. The disadvantage of this approach is obligatory solubility of the template molecule in aqueous solutions, which makes impossible the development of sensors for water-insoluble analytes.

An alternative approach is based on special features of an analyte, which can be used for the detection of the MIP-analyte binding event (the analyte can be either fluorescent [154, 169, 170] or electroactive [171]). Suarez-Rodriguez and Diaz-Garcia used HPLC with fluorescent detection as a sensor system for detection of fluorescent substance flavonol in nanomolar range [170].

In the case when the analyte is neither fluorescent nor electroactive, competitive analysis based on application of the labeled analyte is used. The labeled analyte compete with the paternal one for the selective sites of the polymer [134, 172-175]. Haupt et al. developed a sensor for 2,4-D detection. The sensor is based on competition of 2,4-D and its analogue labeled either with fluoresceinethiocyanate or ${ }^{14} \mathrm{C}$. Application of both labels provided 2,4-D detection with the detection limit $100 \mathrm{nM}$ in a competitive assay.

The best results in development of MIP-based sensors would be achieved, when the sensor signal is generated directly by the polymer and is not dependent on properties of the template molecule. That would result in significant facilitation of the analysis. A typical example is modification of MIPs with signal groups capable of either generation or amplification of the sensor response [149, 176-179]. Turkewitsch et al. and Matsui et al. proposed application of fluorescent functional

monomers

(trans-4-[n-(N,N'-diethylamino)styryl]-N-vinylbenzyl pyridinechloride and fluorescent metaloporphyrine, respectively) for the synthesis of molecularly imprinted polymers $[149,176]$. Binding of cAMP and 9-ethyladenine with these functional monomers results in a decrease in the polymer fluorescence, which is proportional to the analyte concentration. During the recent years, molecularly imprinted polymers based on cross-linked fluorescent poly-(n-phenylenevinylene) were synthesized. At the same time, the binding event MIP - 2,4,6,-trinitrotoluene changes natural fluorescence of the polymer [180]. The devices, based on MIPs modified with signal groups, provide a possibility of analyte detection in micromolar range.

Much more universal approach towards development of MIP-based sensors capable of generation of the sensor response was proposed by our group $[181,182]$. The approach is based on application of molecularly imprinted polymer membranes able to change their electrical conductivity in the presence of template molecules (particularly triazine herbicides), which was detected by a conductometric method. The change of electrical conductivity of the MIP membranes was proportional to triazines concentration within the range 5-100 nM. The analysis doesn't require labeling neither polymer nor analyte.

Existing pseudoimmuno/pseudoenzyme MIP-based sensors can be affiliated either to electrochemical (amperometric [171, 183], potentiometric [181, 187], capacitive [167, 188]) or optical (fluorescent [149, 169], acoustic [155], colorimetric [173]) sensors.

Effectiveness of MIP application as selective elements of pseudoimmunosensor devises was demonstrated by the numerous investigations. MIPs provide highly selective detection of different analytes, which is similar or better (with respect to selectivity) as compared to the similar immunosensor devises. The main problems arising during development of MIP-based sensors are associated with registration of the MIP-analyte binding event as well as integration of MIPs with physical transducers. That can be the main reason for poor sensitivity of the developed sensors. These problems can be solved through development of the universal method of synthesis of molecularly imprinted polymers capable of both recognition of corresponding analytes and generation of the sensor signal.

Development of analytical methods based on molecularly imprinted polymers is a promising area of modern biotechnology. Application of MIPs in chromatography, solid-phase extraction, pseudoimmunoassay, and sensor technology is an attractive alternative to the application of bioreceptors and enzymes. The main problems associated with 
application of MIPs in biotechnology are caused by technological difficulties arising during application of MIP particles in separation and sensing. The most promising area in practical application of MIPs is development of highly-stable polymers-biomimics in a form of membranes and thin films.

Financial support from National Academy of sciences of Ukraine (programs "Sensor systems for medical-ecological and industrial purposes" and "Novel medical-biological problems and human environment")

\section{T. А. Сергеєва}

Молекулярно-імпринтовані полімери як штучні аналоги біологічних рецепторів.

2. Практичне застосування у новітній біотехнології

Резюме

Огляд присвячено аналізу робіт у галузі отримання штучних аналогів біологічних рецепторів та їхному практичному застосуванню в біотехнології. Основну увагу в иььому сенсі приділено таким галузям новітньої біотехнології, як сенсорна технологія, твердофазова екстракція, псевдоімуноаналіз, а також хроматографія.

Ключові слова: молекулярний імпринтинг, молекулярно-імпринтовані полімери, полімери-біоміметики.

\section{T. А. Сергеева}

Молекулярно-импринтированные полимеры как искусственные аналоги биологических рецепторов.

2. Практическое применение в современной биотехнологии

Резюме

Обзор посвящен анализу работ в области получения искусственных аналогов биологических рецепторов и их практическому применению в современной биотехнологии. Особое внимание в этом плане уделено таким областям биотехнологии, как сенсорная технология, твердофазовая экстракичи, псевдоиммуноанализ, а также хроматография.

Ключевые слова: молекулярный импринтинг, молекулярно-импринтированные полимеры, полимеры-биомиметики.

\section{REFERENCES}

1. Sergeyeva T. A. Molecularly imprinted polymers as synthetic mimicks of bioreceptors. 1. General principles of molecular imprinting // Biopolymers and Cell.-2009.-25, N 4.-P. 253265.

2. Sanbe H., Haginaka J. Restricted access media-molecularly imprinted polymer for propranolol and its application to direct injection analysis of beta-blockers in biological fluids // Analyst.-2003.-128, N 6.-P. 593-597.
3. Lai J.-P., CaoX. F., Wang X. L., He X. W. Chromatographic characterization of molecularly imprinted microspheres for the separation and determination of trimethoprim in aqueous buffers // Anal. Bioanal. Chem.-2002.-372, N 2.-P. 391396.

4. Allender C. J., Brain K. R., Ballatore C., Cahard D., Siddiqui A., McGuigan C. Separation of individual antiviral nucleotide prodrugs from synthetic mixtures using cross-reactivity of a molecularly imprinted stationary phase // Anal. Chim. Acta.-2001.-435, N 1.-P. 107-113.

5. Yan L. S., Wang Z. H., Luo G., Wang Y. M. Determination of caffeine by micro high performance liquid chromatography with a molecularly imprinted capillary monolithic column // Chin. J. Anal. Chem.-2004.-32, N 2.-P. 148-152.

6. Gill R. S., Marquez M., Larsen G. Molecular imprinting of a cellulose/silica composite with caffeine and its characterization // Microporous and Mesoporous Materials.-2005.-85, N 1-2.-P. 129-135.

7. Hwang C. C., Lee W. C. Chromatographic resolution of the enantiomers of phenylpropanolamine by using molecularly imprinted polymer as the stationary phase // J. Chromatogr. B.-2001.-765, N 1.-P. 45-53.

8. Lai J. P., LuX. Y., Lu C. Y., Ju H.F., HeX.W. Preparation and evaluation of molecularly imprinted polymeric microspheres by aqueous suspension polymerization for use as a highperformance liquid chromatography stationary phase // Anal. Chim. Acta.-2001.-442, N 1.-P. 105-111.

9. Piletska E. V., Romero-Guerra M., Guerreiro A. R., Karim K., Turner A. P. F., Piletsky S. A. Adaptation of the molecular imprinted polymers towards polar environment // Anal. Chim. Acta.-2005.-542, N 1.-P. 47-51.

10. Kim H., Kaczmarski K., Guiochon G. Intraparticle mass transfer kinetics on molecularly imprinted polymers of structural analogues of a template // Chem. Eng. Sci.-2001.-61, N 4.-P. 1122-1137.

11. Simon R., Houck S., Spivak D. A. Comparison of particle size and flow rate optimization for chromatography using onemonomer molecularly imprinted polymers versus traditional non-covalent molecularly imprinted polymers // Anal. Chim. Acta.-2005.-542, N 1.-P. 104-110.

12. Sun R., Yu H., Luo H., Shen Z. Construction and application of a stoichiometric displacement model for retention in chiral recognition of molecular imprinting // J. Chromatogr. A.2004.-1055, N 1-2.-P. 1-9.

13. Lu Y., Li C., Liu X., Huang $W$. Molecular recognition through the exact placement of functional groups on non-covalent molecularly imprinted polymers // J. Chromatogr. A.-2002.950, N 1-2.-P. 89-97.

14. Striegler S., Tewes E. Investigation of sugar-binding sites in ternary ligand-copper(II)-carbohydrate complexes // Eur. J. Inorg. Chem.-2002.-N 2.-P. 487-495.

15. Striegler S. Carbohydrate recognition in cross-linked sugartemplated poly(acrylates) // Macromolecules.-2003.-36, N 4.-P. 1310-1317.

16. Wulff G., Schauhoff S. Racemic resolution of free sugars with macroporous polymers prepared by molecular imprinting. Selectivity dependence on the arrangement of functional groups versus spatial requirements // J. Org. Chem.-2001.56, N1.-P. 395-400.

17. Baggiani C., Giraudi G., Giovannoli C., Trotta F., Vanni A. Chromatographic characterization of molecularly imprinted 
polymers binding the herbicide 2,4,5-trichlorophenoxyacetic acid // J. Chromatogr. A.-2000.-883, N 1-2.-P. 119-126.

18. Tamayo F. G., Martin-Esteban A. Selective high performance liquid chromatography imprinted-stationary phases for the screening of phenylurea herbicides in vegetable samples // J. Chromatogr. A.-2005.-1098, N 1-2.-P. 116-122.

19. Prasad B. B., Banerjee $S$. Determination of diquat herbicide by selective enrichment by column chromatography on imprinted polymer immobilised on silica gel // Chromatographia.-2002.-55, N 3-4.-P. 171-176.

20. Baggiani C., Anfossi L., Baravalle P., Giovannoli C., Tozzi $C$. Selectivity features of molecularly imprinted polymers recognising the carbamate group // Anal. Chim. Acta.-2005.531, N 2.-P. 199-207.

21. Bruggemann O., Visnjevski A., Burch R., Patel P. Selective extraction of antioxidants with molecularly imprinted polymers // Anal. Chim. Acta.-2004.-504, N 1.-P. 81-88.

22. Andersson L. I., Muller R., Mosbach K. Molecular imprinting of the endogenous neuropeptide Leu-5 enkephalin and some derivatives thereof // Macromol. Res. Communs.-1996.-17, N 1.-P. 65-71.

23. Yano K., Nakagiri T., Takeuchi T., Matsui J., Ikebukuro K., Karube I. Stereoselective recognition of dipeptide derivatives in molecularly imprinted polymers which incorporate an L-valine derivative as a novel functional monomer // Anal. Chim. Acta.-1997.-357, N 1-2.-P. 91-98.

24. Rachkov A., Hu M., Bulgarevich E., Matsumoto T., Minoura $N$. Molecularly imprinted polymers prepared in aqueous solution selective for [Sar1, Ala8]angiotensin II // Anal. Chim. Acta.-2004.-504, N 1.-P. 191-197.

25. Janiak D. S., Kofinas $P$. Molecular imprinting of peptides and proteins in aqueous media // Anal. Bioanal. Chem.-2007.389, N 2.-P. 399-404.

26. Janotta M., Weiss R., Mizaikoff B., Bruggemann O., Ye L., Mosbach $K$. Molecularly imprinted polymers for nitrophenols - An advanced separation material for environmental analysis // Int. J. Environ. Anal. Chem.-2001.-80, N 2.P. 75-86.

27. Moller K., Nilsson U., Crescenzi C. Synthesis and evaluation of molecularly imprinted polymers for extracting hydrolysis products of organophosphate flame retardants // J. Chromatogr. A.-2001.-938, N 1-2.-P. 121-130.

28. Ansell R. J., Mosbach K. Molecularly imprinted polymers by suspension polymerisation in perfluorocarbon liquids, with emphasis on the influence of the porogenic solvent // J. Chromatogr. A.-1997.-787, N 1-2.-P. 55-66.

29. Flores A., Cunliff D., Whitcombe M. J., Vulfson E. N. Imprinted polymers prepared by aqueous suspension polymerization // J. Appl. Polym. Sci.-2000.-77, N 8.-P. 1841-1850.

30. Zhang L. Y., Cheng G. X., Fu C., Liu X. H. Tyrosine imprinted polymer beads with different functional monomers via seed swelling and suspension polymerization // Polym. Eng. Sci.2003.-43, N 3.-P. 965-974.

31. Li Y. C., Fu Q. Q., Zhang Q. Q., He L. C. Preparation and evaluation of uniform-size (-)-ephedrine-imprinted polymeric microspheres by multi-step swelling and suspension polymerisation // Anal. Sci.-2006.-22, N 10.-P. 1355-1360.

32. Haginaka J., Tabo H., Ichitani M., Takihara T., Sugimoto A. Sambe $H$. Uniformly-sized, molecularly imprinted polymers for (-)-epigallocatechin gallate, -epicatechin gallate and gallocatechin gallate by multi-step swelling and polymerization method // J. Chromatogr. A.-2007.-1156, N 1-2.-P. 45-50.

33. Liu X. J., Chen Z. Y., Zhao R., Shangguan D., Liu G. Q., Chen $Y$. Uniform-sized molecularly imprinted polymer for metsul- furon-methyl by one-step swelling and polymerization method // Talanta.-2007.-71, N 3.-P. 1205-1210.

34. Sambe H., Hoshina K., Haginaka J. Molecularly imprinted polymers for triazine herbicides prepared by multi-step swelling and polymerization method - Their application to the determination of methylthiotriazine herbicides in river water// J. Chromatogr. A.-2007.-1152, N 1-2.-P. 130-137.

35. Tamayo F. G., Titirici M. M., Martin-Esteban A., Sellergren $B$. Synthesis and evaluation of new propazine-imprinted polymer formats for use as stationary phases in liquid chroma- tography // Anal. Chim. Acta.-2005.-542, N 1.P. 38-46.

36. Kim H. J., Guiochon G. Comparison of the thermodynamic properties of particulate and monolithic columns of molecularly imprinted copolymers // Anal. Chem.-2005.-77, N 1.P. 93-102.

37. Jin H. L., Row K. H. Special selectivity of molecularly imprinted monolithic stationary phase // J. Liq. Chromatogr. Relat. Technol.-2005.-28, N 20.-P. 3147-3155.

38. Sun H. W., Qiao F. X., Liu G. Y. Characteristic of theophylline imprinted monolithic column and its application for determination of xanthine derivatives caffeine and theophylline in green tea // J. Chromatogr. A.-2006.-1134, N 1-2.P. 194-200.

39. Haginaka J., Futagami A. Addition of N-carbobenzyloxy1-tryptophan as a co-template molecule to molecularly imprinted polymer monoliths for (+)-nilvadipine // J. Chromatogr. A.-2008.-1185, N 2.-P. 258-262.

40. Lui H., Zhuang X., Turson M., Zhang M., Dong X. Enrofloxacin-imprinted monolithic columns synthesized using reversible addition-fragmentation chain transfer polymerization // J. Separ. Sci.-2008.-31, N 10.-P. 1694-1701.

41. Yan H., Row K. H. Novel molecularly imprinted monolithic column for selective on-line extraction of ciprofloxacin from human urine // Biomed. Chromatogr.-2008.-22, N 5.P. 487-493.

42. Seebach A., Seidel-Morgenstern A. Enantioseparation on molecularly imprinted monoliths - Preparation and adsorption isotherms // Anal. Chim. Acta.-2007.-591, N 1.-P. 57-62.

43. Svec F. Less common applications of monoliths: Preconcentration and solid-phase extraction // J. Chromatogr. B.2006.-841, N 1-2.-P. 52-64.

44. Masque N., Marce R. M., Borrul F. Molecularly imprinted polymers: new tailor-made materials for selective solid-phase extraction // Trends Anal. Chem.-2001.-20, N 9.- P. 477486.

45. Owens P. K., Karlsson L., Lutz E. S. M., Andersson L. I. Molecular imprinting for bio- and pharmaceutical analysis // Trends Anal. Chem.-1999.-18, N 3.-P. 146-154.

46. Ferrer I., Barcello D. Validation of new solid-phase extraction materials for the selective enrichment of organic contaminants from environmental samples // Trends Anal. Chem.1999.-18, N 3.-P. 180-192.

47. Poole C. F. New trends in solid-phase extraction // Trends Anal. Chem.-2003.-22, N 6.-P. 362-373.

48. Sellergren $B$. Direct drug determination by selective sample enrichment on an imprinted polymer // Anal. Chem.-1994.66, N 9.-P. 1578-1582.

49. Suedee R., Seechamnanturakit V., Canyuk B., Ovatiarnporn C., Martin G. P. Temperature sensitive dopamine-imprinted (N,N'-methylene-bis-acrylamide cross-linked) polymer and its potential application to the selective extraction of adrenergic drugs from urine // J. Chromatogr. A.-2006.-1114, N 2.-P. 239-249. 
50. Martin P. D., Jones G. R., Stringer F., Willson I. D. Comparison of normal and reversed-phase solid-phase extraction methods for extraction of beta-blockers from plasma using molecularly imprinted polymers // Analyst.-2003.-128, N 4.-P. 345-350.

51. Sambe H., Hoshina K., Hosoya K., Haginaka J. Direct injection analysis of bisphenol A in serum by combination of isotope imprinting with liquid chromatography-mass-spectrometry // Analyst.-2005.-130, N 1.-P. 38-40.

52. Mullet W., Dirie M., Lai E. P. C., Guo H., He X. A 2-aminopyridine molecularly imprinted polymer surrogate microcolumn for selective solid-phase extraction and determination of 4-aminopyridine // Anal. Chim. Acta.-2000.-414, N 1-2.-P. 123-131.

53. Crescenzi C., Bayoudth S., Cormack P. A. G., Klein T., Ensing $K$. Determination of clenbuterol in bovine liver by combining matrix solid-phase dispersion and molecularly imprinted solid-phase extraction followed by liquid chromatography/electrospray ion trap multiple stage mass spectrometry // Anal. Chem.-2001.-73, N 10.-P. 2171-2177.

54. Caro E., Marce R. M., Cormack P. A. G., Sherrington D. C., Borrol $F$. A new molecularly imprinted polymer for the selective extraction of naproxen from urine samples by solidphase extraction // J. Chromatogr. B.-2004.-5813, N 1-2.P. 137-143.

55. Abdel-Rehim M., Andersson L. I., Altun Z., Blomberg L. G. Microextraction in packed syringe online with liquid chromatography-tandem mass spectrometry: molecularly imprinted polymer as packing material for MSPE in selective extraction of ropivacaine from plasma // J. Liq. Chromatogr.2006.-29.-P. 1725-1736.

56. Cobb Z., Sellergren B., Andersson L. I. Water-compatible molecularly imprinted polymers for efficient direct injection on-line solid-phase extraction of ropivacaine and bupivacaine from human plasma // Analyst.-2007.-132, N 12.P. 1262-1271.

57. Cacho C., Turiel E., Martin-Esteban A., Perez-Conde C., Camara $C$. Clean-up of triazines in vegetable extracts by molecularly-imprinted solid-phase extraction using a propazineimprinted polymer // Anal. Bioanal. Chem.-2003.-376, N 4.P. 491-496.

58. dePrada A. G. V., Ruiz-Martinez P., Reviejo A. J., Pingarron $J$. M. Solid-phase molecularly imprinted on-line preconcentration and voltammetric determination of sulfamethazine in milk // Anal. Chim. Acta.-2005.-539, N 1-2.P. 125-132.

59. Piletsky S., Piletska E., Karim K., Foster G., Legge C., Turner $A$. Custom synthesis of molecular imprinted polymers for biotechnological application: Preparation of a polymer selective for tylosin // Anal. Chim. Acta.-2004.-504, N 1.-P. $123-$ 130.

60. Puoci F., Carreffa C., Iemma F., Muzzalupo R., Spizzirri U. G., Picci N. Molecularly imprinted solid-phase extraction for detection of sudan I in food matrices // Food Chem.-2005.93, N 2.-P. 349-353.

61. Farrington K., Magner E., Regan F. Predicting the performance of molecularly imprinted polymers: selective extraction of caffeine by molecularly imprinted solid-phase extraction // Anal. Chim. Acta.-2006.-566, N 1.-P. 60-68.

62. Liu Q., Zhou Y. X., Meng Z. H., Wang Q. Q., Xu X. Y., Liu Y. T. Determination of nerve agent degradation products in rice by molecular imprinting polymer solid-phase extraction and capillary electrophoresis // Clin. J. Anal. Chem.-2001.-29, N 4.-P. 387-390.
63. Molinelli A., Weiss R., Mizaikoff B. Advanced solid-phase extraction using molecularly-imprinted polymers for the determination of quercetin in red wine // J. Agric. Food. Chem.2002.-50, N 7.-P. 1804-1808.

64. Lai J. P., Niessner R., Knopp D. Benzo[a]pyrene imprinted polymers: synthesis, characterization and SPE application in water and coffee samples // Anal. Chim. Acta.-2004.-522, N 2.-P. 137-144.

65. Zhou S. N., Lai E. P. C., Miller J. D. Analysis of wheat extracts for ochratoxin A by molecularly imprinted solid-phase extraction and pulsed elution // Anal. Bioanal. Chem.2004.-378, N 8.-P. 1903-1906.

66. Turner N. W., Piletska E. V., Karim K., Whitcombe M., Malecha M., Magan N., Baggiani C., Piletsky S. A. Effect of the solvent on recognition properties of molecularly imprinted polymer specific for ochratoxin A // Biosensors and Bioelectronics.-2004.-20, N 6.-P. 1060-1067.

67. Zhu X. L., Yang J., Su Q. D., Cai J. B., Gao Y. Selective solidphase extraction using molecularly imprinted polymer for the analysis of polar organophosphorus pesticides in water and soil samples // J. Chromatogr. A.-2005.-1092, N 2.-P. 161169.

68. Gallego-Gallegos M., Liva M., Olivas R. M., Camara C. Focused ultrasound and molecularly imprinted polymers: a new approach to organotin analysis in environmental samples // J. Chromatogr. A.-2006.-1114, N 1.-P. 82-88.

69. Tamayo F. G., Casillas J. L., Martin-Esteban A. Clean-up of phenylurea herbicides in plant sample extracts using molecularly imprinted polymers // Anal. Bioanal. Chem.-2005.381, N 6.-P. 1234-1240.

70. Martin-Esteban A., Turiel E., Stevenson D. Effect of template size on the selectivity of molecularly imprinted polymers for phenylurea herbicides // Chromatographia.-2001.-53 (Special issue).-P. S434-437.

71. Mena M. L., Martinez-Ruiz P., Reviejo A. J., Pingarron J. M. Molecularly imprinted polymers for on-line preconcentration by solid-phase extraction of primicarb in water samples // Anal. Chim. Acta.-2002.-451, N 2.-P. 297-304.

72. Zhu O. Z., deGelmann P., Niessner R., Knopp D. Selective trace analysis of sulfonylurea herbicides in water and soil samples based on solid-phase extraction using a molecularly imprinted polymer // Environ. Sci. Technol.-2002.-36, N 24.-P. 5411-5420.

73. Tamayo F. G., Casillas J. L., Martin-Esteban A. Highly selective fenuron-imprinted polymer with a homogeneous binding site distribution prepared by precipitation polymerization and its application to the clean-up of fenuron in plant samples // Anal. Chim. Acta.-2003.-482, N 2.-P. 165-173.

74. Baggiani C., Giovannoli C., Anfossi L., Tozzi C. Molecularly imprinted solid-phase extraction sorbent for the clean-up of chlorinated phenoxyacids from aqueous samples // J. Chromatogr. A.-2001.-938, N 1-2.-P. 35-44.

75. Caro E., Marce R. M., Cormack P. A. G., Sherrington D. C., Borrul F. Molecularly imprinted solid-phase extraction of naphthalene sulfonates from water // J. Chromatogr. A.-2004.1047, N 2.-P. 175-180.

76. Say R., Ersoz A., Turk H., Denizli A. Selective separation and pre-concentration of cyanide by a column packed with cyanide-imprinted polymeric microbeads // Sep. Purif. Technol.-2004.-40, N 1.-P. 9-14.

77. Chianella I., Piletsky S. A., Tothill I. E., Chen B., Turner A. P. MIP-based solid-phase extraction cartridges combined with MIP-based sensors for the determination of microcystin-LR // Biosensors and Bioelectronics.-2003.-18, N 2.-P. 119-127. 
78. Perez-Moral N., Mayes A. G. Comparative study of imprinted polymer particles prepared by different polymerisation methods // Anal. Chim. Acta.-2004.-504, N 1.-P. 15-21.

79. Turiel E., Tadeo J. L., Cormack P. A. G., Martin-Esteban A. HPLC imprinted-stationary phase prepared by precipitation polymerisation for the determination of thiabendazole in fruit // Analyst.-2005.-130, N 12.-P. 1601-1608.

80. Perez-Moral N., Mayes A. G. Direct rapid synthesis of MIP beads in SPE cartridges // Biosensors and Bioelectronics.2006.-21, N 9.-P. 1798-1803.

81. Sanbe H., Hoshina K., Haginaka J. Direct injection analysis of bisphenol A in serum by combination of isotope imprinting with liquid chromatography-mass spectrometry // Analyst.2005.-130, N 1.-P. 38-46.

82. Kubo T., Nomachi M., Nemoto K., Sano T., Hosoya K., Tanaka N., Kaya K. Chromatographic separation for domoic acid using a fragment imprinted polymer // Anal. Chim. Acta.2006.-577, N 1.-P. 1-7.

83. Sanbe H., Haginaka J. Restricted access media-molecularly imprinted polymer for propranolol and its application to direct injection analysis of $\beta$-blockers in biological fluids // Analyst.-2003.-128, N 6.-P. 593-598.

84. Watabe Y., Kondo T., Morita M., Tanaka N., Haginaka J., Hosoya $K$. Determination of bisphenol A in environmental water at ultra-low level by high performance liquid chromatography with an effective on-line pre-treatment device // J. Chromatogr. A.-2004.-1032, N 1-2.-P. 9-45.

85. Kubo T., Hosoya K., Watabe Y., Ikegami T., Tanaka N., Sano $T$., Kaya K. On-column concentration of bisphenol A with one-step removal of humic acids in water // J. Chromatogr. A.-2003.-987, N 1-2.-P. 389-394.

86. Ou J., Kong L., Pan C., Su X., Lei X., Zou H. Determination of dl-tetrahydropalmatine in Corydalis yanhusuo by 1-tetrahydropalmatine imprinted monolithic column coupling with reversed-phase high performance liquid chromatography // J. Chromatogr. A.-2006.-117, N 2.-P. 163-169.

87. Xie J., Zhu L., Xu X. Affinitive separation and on-line identification of antitumor components from Peganum nigellastrum by coupling a chromatographic column of target analogue imprinted polymer with mass spectrometry // Anal. Chem.-2002.-74, N 10.-P. 2352-2360.

88. Haginaka J., Sanbe H. Uniform-sized molecularly imprinted polymers for 2-arylpropionic acid derivatives selectively modified with hydrophilic external layer and their applications to direct serum injection analysis // Anal. Chem.-2000.-72, N 21.-P. 5206-5210.

89. Hu S., Wang S. W., He X. W. An amobarbital molecularly imprinted microsphere for selective solid-phase extraction of phenobarbital from human urine and medicines and their determination by high-performance liquid chromatography // Analyst.-2003.-128, N 12.-P. 1485-1489.

90. Theodoridis G., Kantifes A., Manesiotis P., Raikos N., Tsoukali-Papandopoulou H. Preparation of a molecularly-imprinted polymer for the solid-phase extraction of scopolamine with hyoscyamine as a dummy template molecule // J. Chromatogr. A.-2003.-987, N 1-2.-P. 103-109.

91. Andersson L. I., Paprica A., Arvidsson T. A highly selective solid phase extraction sorbent for pre-concentration of sameridine made by molecular imprinting // Chromatographia.-1997.-46, N 1-2.-P. 57-62.

92. Wang J. C., Guo R. B., Chen J. P., Zhang Q., Liang X. M. Phenylurea herbicides-selective polymer prepared by molecular imprinting using $\mathrm{N}$-(4-isopropylphenyl)-N'-butyleneurea as dummy template // Anal. Chim. Acta.-2005.-540, N 1-2.P. 307-315.

93. Matsui J., Fujiwara K., Takeuchi T. Atrazine-selective polymers prepared by molecular imprinting of trialkylmelamines as dummy template species of atrazine // Anal. Chem.-2000.72, N 8.-P. 1810-1813.

94. Urraca J. L., Marazuela M. D., Merino E. R., Orellana G., Moreno-Bondi M. C. Molecularly imprinted polymers with a streamlined mimic for zearalenone analysis // J. Chromatogr. A.-2006.-1116, N 1-2.-P. 127-134.

95. Jodlbauer J., Maier N. M., Lindner W. Towards ochratoxin A selective molecularly imprinted polymers for solid-phase extraction // J. Chromatogr. A.-2002.-945, N 1.-P. 45-63.

96. Chianella I., Karim K., Piletska E. V., Preston C., Piletsky S. $A$. Computational design and synthesis of molecularly imprinted polymers with high binding capacity for pharmaceutical applications-model case: adsorbent for abacavir // Anal. Chim. Acta.-2006.-559, N 1.-P. 73-78.

97. Koster M. E. H., Crescenzi C., Hoedt W. D., Ensing K., de Jong G. J. Fibers coated with molecularly imprinted polymers for solid-phase microextraction // Anal. Chem.-2001.73, N 13.-P. 3140-3145.

98. Нu X., Hu Y., Li G. Development of novel molecularly imprinted solid-phase microextraction fiber and its application for the determination of triazines in complicated samples coupled with high-performance liquid chromatography // J. Chromatogr. A.-2007.-1147, N 1.-P. 1-9.

99. Yu J. C. C., Krushkova S., Lai E. P. C., Dabek-Zlotorzynska E. Molecularly-imprinted polypyrrole-modified stainless ste- el frits for selective solid phase preconcentration of ochrato- xin A // Anal. Bioanal. Chem.-2005.-382, N 7.-P. 1534- 1540.

100. Xie S., Svec F., Frechet J. Porous polymer monoliths: preparation of sorbent materials with high-surface areas and controlled surface chemistry for high-throughput, online, solid-phase extraction of polar organic compounds // Chem. Mater.-1998.-10, N 12.-P. 4072-4078.

101. Tan A., Benetton S., Henion J. Chip-based solid-phase extraction pretreatment for direct electrospray mass spectrometry analysis using an array of monolithic columns in a polymeric substrate // Anal. Chem.-2003.-75, N 20.-P. 55045511.

102. Ou J., Hu L., Hu L., Li X., Zou H. Determination of phenolic compounds in river water with on-line coupling bisphenol A imprinted monolithic precolumn with high performance liquid chromatography //Talanta.-2006.-69, N 4.-P. 1001-1006.

103. Zhang M., Xie J., Zhou Q., Chen G., Liu Z. On-line solidphase extraction of ceramides from yeast with ceramide III imprinted monolith // J. Chromatogr. A.-2003.-984, N 2.P. 173-183.

104. Courtois J., Fischer G., Sellergren B., Irgum K. Molecularly imprinted polymers grafted to flow through poly(trimethylolpropane trimethacrylate) monoliths for capillary-based solidphase extraction // J. Chromatogr. A.-2006.-1109, N 1.P. 92-99.

105. Pat. of Ukraine UA82805C2. Polymeric membrane for selective adsorbtion of herbicides (variants) / T. A. Sergeyeva, O. O. Brovko, V. F. Matyushov, L. A. Goncharova, L. M. Sergeyeva, L. V. Stepanenko, G. V. El'ska // Bull. N 9. 12.05.2008.

106. Eur. pat. EP 1521800 . Porous molecularly-imprinted polymer membranes / S. A. Piletsky, O. V. Piletska, A. P. F. Turner, P. J. Warner P. J., Sergeyeva T. A., Brovko O. O., Elska G. V. Porous molecularly-imprinted polymer membranes // Publ. 13.07.2002. 
107. Sergeyeva T. A., Piletsky S. A., Piletska E. V., Brovko O. O., Karabanova L. V., Sergeyeva L. M., El'skaya A. V. Synthesis of molecularly imprinted polymer membranes for solid-phase extraction of triazine herbicides from aqueous solutions // Dopovidi NAN Ukrainy.-2003.-N 6.-P. 170-174.

108. Sergeyeva T. A., Piletsky S. A., Piletska E. V., Brovko O. O., Karabanova L. V., Sergeeva L. M., Turner A. P. F., E'lskaya A. V. In situ formation of porous molecularly imprinted polymer membranes // Macromolecules.-2003.-36, N 19.P. 7352-7357.

109. Sergeyeva T. A., Brovko O. O., Piletska E. V., Piletsky S. A., Goncharova L. A., Karabanova L. V., Sergeeva L. M., E'lskaya $A$. $V$. Porous molecularly imprinted polymer membranes and polymeric particles // Anal. Chim. Acta.-2007.-582, N 2.-P. 311-319.

110. Sergeyeva T. A., Piletska O. V., Piletsky S. A., Sergeeva L. M., Brovko O. O., E'lska G. V. Data on structure and recognition properties of template-selective binding sites in semiIPN-based molecularly imprinted polymer membranes // Mater. Sci. and Eng. C.-2008.-28, N 8.-P. 1482-1479.

111. Sergeyeva T. A., Piletska O. V., Brovko O. O., Goncharova L. A., Piletsky S. A., El'ska G. V. Aflatoxin-selective molecularly imprinted polymer membranes based on acrylate-polyurethane semi-interpenetrating polymer networks // Ukr. Biokhim. Zhur.-2007.-79, N 5.-P. 109-115.

112. Sergeyeva T. A., Piletska O. V., Goncharova L. A., Brovko O. O., Piletsky S. A., El'ska G. V. Sensor system based on molecularly imprinted polymer membranes for selective recognition of aflatoxin B1 // Ukr. Biokhim. Zhur.-2008.-80, N 3.P. 84-93.

113. Brovko O. O., Sergeyeva T. A., Goncharova L. A., Shtompel V. I., Kochetov O. O., Sergeeva L. M., Elska G. V. Structure and properties of polymer membranes based on semi-interpenetrating polymer networks // Ukr. Khim. Zhur.-2006.-22, N 7.-P. 42-47.

114. Karabanova L. V., Brovko O. O., Sergeyeva T. A., Lutsyk O. D., Goncharova L. A., Kochetov O. O. Structural and morphological special features of molecularly imprinted polymer membranes synthesized according to the IPN principle // Polymernyi Zhur.-2008.-30, N 2.-P. 111-115.

115. Karabanova L. V., Brovko O. O., Sergeyeva T. A., Goncharova L. A., Lutsyk O. D. Thermodynamics of interactions between polymer components during synthesis of toxin-selective molecularly imprinted polymer membranes, synthesized according to the IPN principle // Polymernyi Zhur.-2009.-31, N 1.-P. 162-169.

116. Goncharova L. A., Brovko O. O., Shtompel V. I., Sergeyeva T. A., Karabanova L. V., Sergeyeva L. M., Kochetov O. O., Svyatina A. V. Microporous films based on polyurethane-polyurethaneacrylate semi-interpenetrating polymer networks // Polymernyi Zhur.-2007.-29, N 4.-P. 271-280.

117. Eur. Pat. EP 1244516A1. Verfahren zur herstellung templatgepragter materialien mit honer bindungspezifitat und selektivitat und ihre verwendung / M. Ulbricht, T. A. Sergeyeva, H. Matuschewski, U. Schedler, S. A. Piletsky // Publ. 01.12.2000.

118. Sergeyeva T. A., Matuschewski H., Piletsky S. A., Bendig J., Schedler U., Ulbricht M. Molecularly imprinted polymer membranes for substance-selective solid-phase extraction from water by surface photo-grafting technique // J. Chromatogr. A.-2001.-907, N 1-2.-P. 89-99.

119. Sergeyeva T. A., Matuschewski H., Piletsky S. A., Shedler U., Ulbricht $M$. Development of molecularly imprinted polymer membranes with specificity to triazine herbicides prepared by the «surface photo-grafting technique»// Biopolymers and Cell.-2004.-20, N 4.-P. 307-314.

120. Matuschewski H., Sergeyeva T. A., Bendig J., Piletsky S. A., Ulbricht M., Shedler U. Surface engineering: molecularly imprinted affinity membranes by photograft polymerization // Proc. SPIE.-2001.-4205.-P. 65-74.

121. Yallow R. S., Berson S. A. Assay of plasma insulin in human subjects by immunological methods // Nature.-1959.-184, N 4699.-P. 1648-1649.

122. Gonzalez-Martinez M. A., Puchades R., Maquieira A. On-line immunoanalysis for environmental pollutants: from batch assays to automated sensors // TrAC Trends Anal. Chem.1999.-18, N 3.-P. 204-218.

123. Degelau A., Freitag R., Linz F., Middendorf C., Scheper T., Bley T., Muller S., Stoll P., Reardon K. F. Immuno- and flow cytometric analytical methods for biotechnological research and process monitoring // J. Biotechnol.-1992.-25, N 1-2.P. 115-144.

124. Franek M., Hruska K. Antibody based methods for environmental and food analysis: a review // Veterin. Med.-Czech.2005.-50, N 1.-P. 1-10.

125. Vlatakis G., Andersson L. I., Muller R., Mosbach K. Drug assay using antibody mimics made by molecular imprinting // Nature.-1993.-361, N 6413.-P. 645-647.

126. Andersson L. I., Muller R., Vlatakis G., Mosbach K. Mimics of the binding sites of opiod receptors obtained by molecular imprinting of enkephalin and morphine // Proc. Nat. Acad. Sci. USA.-1995.-92, N 11.-P. 4788-4792.

127. Yilmaz E., Mosbach K., Haupt K. Influence of functional and cross-linking monomers and the amount of template on the performance of molecularly imprinted polymers in binding assays // Anal. Communs.-1999.-36, N 5.-P. 167-170.

128. Andersson L. I. Application of molecular imprinting to the development of aqueous buffer and organic solvent based radioligand binding assays for (S)-propranolol // Anal. Chem.1996.-68, N 1.-P. 111-117.

129. Muldoon M. T., Stanker L. H. Polymer synthesis and characterization of a molecularly imprinted sorbent assay for atrazine // J. Agric. Food. Chem.-1995.-43, N 6.-P. 1424-1427.

130. Siemann M., Andersson L., Mosbach K. Selective recognition of the herbicide atrazine by noncovalent molecularly imprinted polymers // J. Agric. Food. Chem.-1996.-44, N 1.P. 141-145.

131. Ye L., Cormack P. A. G., Mosbach K. Molecularly imprinted monodisperse microspheres for competitive radioassay // Anal. Communs.-1999.-36, N 2.-P. 35-38.

132. Ramstrom O., Ye L., Mosbach K. Artificial antibodies to corticosteroids prepared by molecular imprinting // Chem. Biol.-1996.-3, N 6.-P. 471-477.

133. Urraca J. L., Moreno-Bondi M. C., Orellana G., Sellergren $B$., Hall A. J. Molecularly imprinted polymers as antibody mimics in automated on-line fluorescent competitive assays // Anal. Chem.-2007.-79, N 13.-P. 4915-4923.

134. Benito-Pena E., Moreno-Bondi M. C., Aparicio S., Orellana $G$., Cederfur J., Kempe M. Molecular engineering of fluorescent penicillins for molecularly imprinted polymer assays // Anal. Chem.-2006.-78, N 6.-P. 2019-2027.

135. Haupt K., Dzgoev A., Mosbach K. Assay system for the herbicide 2,4-dichlorophenoxyacetic acid using a molecularly imprinted polymer as an artificial recognition element // Anal. Chem.-1998.-70, N 3.-P. 628-631.

136. Lu C.-H., Zhou W.-H., Han B., Yang H.-H., Chen X., Wang $X$. $R$. Surface-imprinted core-shell nanoparticles for sorbent assays // Anal. Chem.-2007.-79, N 14.-P. 5457-5461. 
137. Haupt $K$. Noncovalent molecular imprinting of a synthetic polymer with the herbicide 2,4-dichlorophenoxyacetic acid in the presence of polar protic solvents // ACS Symp. Ser.-1998.-703.-P. 135-142.

138. Shi H. Q., Tsai W. B., Garisson M. D., Ferrari S., Ratner B. $D$. Template-imprinted nanostructured surfaces for protein recognition // Nature.-1999.-398, N 6728.-P. 593-597.

139. Shi H. Q., Ratner B. D. Template recognition of protein-imprinted polymer surfaces // J. Biomed. Mater. Res.-2000.-49, N 1.-P. 1-11.

140. Surugiu I., Ye L., Yilmaz E., Dzgoev A., Danielsson B., Mosbach $K$., Haupt $K$. An enzyme-linked molecularly imprinted sorbent assay // Analyst.-2000.-125, N 1.-P. 13-16.

141. Surugiu I., Danielsson B., Ye L., Mosbach K., Haupt K. Chemiluminescence imaging ELISA using, instead of an antibody, an imprinted polymer as the recognition element // Anal. Chem.-2001.-73, N 3.-P. 487-491.

142. Surugiu I., Svitel J., Ye L., Haupt K., Danielsson B. Development of a flow injection capillary chemiluminescent ELISA using an imprinted polymer instead of the antibody // Anal. Chem.-2001.-73, N 17.-P. 4388-4392.

143. Piletsky S. A., Piletska E. V., Chen B., Karim K., Weston D., Barret G., Lowe P., Turner A. P. F. Chemical grafting of molecularly imprinted homopolymers to the surface of microplates. Application of artificial adrenergic receptor in enzyme-linked assay for $\beta$-agonists determination // Anal. Chem.2000.-72, N 18.-P. 4381-4385.

144. Piletsky S. A., Piletska E. V., Bossi A., Karim K., Lowe P., Turner A. P. F. Substitution of antibodies and receptors with molecularly imprinted polymers in enzyme-linked and fluorescent assays // Biosensors and Bioelectronics.-2001.-16, N 9.-P. 701-707.

145. Nicholls C., Karim K., Piletsky S., Saini S., Setford S. Displacement imprinted polymer receptor analysis (DIPRA) for chlorophenolic contaminants in drinking water and packaging materials // Biosensors and Bioelectronics.-2006.-21, N 7.-P. 1171-1177.

146. Pat. of Germany, DE 19832598 C2. Oberflachenmodifizierung von mikrotiterplatten mit $\mathrm{pH}$ - und/oder redoxsensitiven und/or molecular gepragten polymeren sowie die verwendung solcher modifizierter mikrotiterplatten in assays bzw. Test- und screeningsystemen / S. A. Piletsky, M. Ulbricht, U. Shedler, O. V. Piletska, T. L. Panasyuk, T. A. Sergeyeva, G. V. E'lska // Publ. 09.07.1998.

147. Piletsky S. A., Piletskaya E. V., Yano K., Kugimiya A., Elgersma A. V., Levi R., Kahlow U., Takeuchi T., Karube I., Panasyuk T. L., E'lskaya A. V. A biomimetic receptor system for sialic acid based on molecular imprinting // Anal. Lett.1996.-29, N 2.-P. 157-170.

148. Wang W., Gao S. H., Wang B. H. Building fluorescent sensors by template polymerization: the preparation of a fluorescent sensor for D-fructose // Org. Lett.-1999.-1, N 8.-P. 12091212 .

149. Turkewitsch P., Wandelt B., Darling C. D., Powell W. S. Fluorescent functional recognition sites through molecular imprinting. A polymer-based fluorescent chemosensor for aqueous cAMP // Anal. Chem.-1998.-70, N 10.-P. 2025-2030.

150. Wandelta B., Mielniczaka A., Turkewitsch P., Wysocki S. Steady-state and time-resolved fluorescence studies of fluorescent imprinted polymers // J. Lumines.-2003.-102-103 (Special ).-P. 774-781

151. Rathbone D. L., Su D., Wang Y., Billington D. C. Molecular recognition by fluorescent imprinted polymers // Tetrahedron Lett.-2000.-41, N 1.-P. 123-126.
152. Rathbone D. L., Ge Y. Selectivity of response in fluorescent polymers imprinted with N1-benzylidene pyridine-2-carboxamidrazones // Anal. Chim. Acta.-2001.-435, N 1.-P. 129136.

153. Malitesta C., Losito I., Zambonin P. G. Molecularly imprinted electrosynthesized polymers: new materials for biomimetic sensors // Anal. Chem.-1999.-71, N 7.-P. 1366-1370.

154. Dickert F. L., Tortschanoff M., Bulst W. E., Fischerauer G. Molecularly imprinted sensor layers for the detection of polycyclic aromatic hydrocarbons in water// Anal. Chem.-1999.71, N 20.-P. 4559-4563.

155. Dickert F. L., Forth P., Lieberzeit P., Tortschanoff M. Molecular imprinting in chemical sensing - Detection of aromatic and halogenated hydrocarbons as well as polar solvent vapors // Fresenius J. Anal. Chem.-1998.-360, N 7-8.-P. 759-762.

156. Dickert F. L., Forth P. Lieberzeit P. A. Voigt G. Quality control of automotive engine oils with mass-sensitive chemical sensors: QCMs and molecularly imprinted polymers // Fresenius J. Anal. Chem.-2000.-366, N 8.-P. 802-806.

157. Dickert F. L., Thierer $S$. Molecularly imprinted polymers for optochemical sensors // Avd. Mater.-1996.-8, N 12.-P. 987990.

158. Haupt K., Noworyta K., Kutner W. Imprinted polymer-based enantioselective acoustic sensor using a quartz crystal microbalance // Anal. Communs.-1999.-36, N 11-12.-P. 391393.

159. Ji H.-S., McNiven S., Ikebukuro K., Karube I. Selective piezoelectric odor sensors using molecularly imprinted polymers // Anal. Chim. Acta.-1999.-390, N 1-3.-P. 93-100.

160. Ji H.-S., McNiven S., Lee K. H., Saito T., Ikebukuro K., Karube $I$. Increasing the sensitivity of piezoelectric odour sensors based on molecularly imprinted polymers // Biosensors and Bioelectronics.-2000.-15, N 7-8.-P. 403-409.

161. Liang C., Peng H., Bao X., Nie L., Yao S. Study of a molecular imprinting polymer coated BAW bio-mimic sensor and its application to the determination of caffeine in human serum and urine // Analyst.-1999.-124, N 12.-P. 1781-1785.

162. Liao H., Zhang Z., Nie L., Yao S. Electrosynthesis of imprinted polyacrylamide membranes for the stereospecific L-histidine sensor and its characterization by AC impedance spectroscopy and piezoelectric quartz crystal technique // J. Biochem. Biophys. Meth.-2004.-59, N 1.-P. 75-87.

163. Jakoby B., Ismail G. M., Byfield M. P., Vellekoop M. J. A novel molecularly imprinted thin film applied to a Love wave gas sensor // Sensors and Actuators.-1999.-76, N 1-3.P. 93-97.

164. Panasyuk-Delaney T., Mirsky V., Sergeyeva T., Wolfbeis $O$. Impedometric chemosensors based on thin film polymers: Proc. of the $7^{\text {th }}$ Int. Workshop on Appl. Phys. of Condensed Matter. (17-19 September, 2001).-Demanovska Dolina, 2001.-P. 199-202.

165. Zayats M., Lahav M., Kharitonov A. B., Willner I. Imprinting of specific molecular recognition sites in inorganic and organic thin layer membranes associated with ion-sensitive fieldeffect transistors // Tetrahedron.-2002.-58, N 4.-P. 815824.

166. Panasyuk-Delaney T., Mirsky V. M., Ulbricht M., Wolfbeis $O$. S. Impedometric herbicide chemosensors based on molecularly imprinted polymers // Anal. Chim. Acta.-2001.-435, N 1.-P. 157-162.

167. Panasyuk-Delaney T., Mirsky V. M., Wolfbeis O. S. Capacitive creatinine sensor based on a photografted molecularly imprinted polymer // Electroanalysis.-2002.-14, N 3.P. 221-227. 
168. Sergeyeva T. A., Panasyuk-Delaney T. L., Piletska O. V., Piletsky S. A., El'ska G. V. Development of a capasitive sensor for environmental monitoring based on molecularly imprinted polymer thin films. Computational modeling for optimization of composition of synthetic mimicks of bioreceptors // Ukr. Biokhim. Zhurn.-2006.-78, N 2.-P. 121-130.

169. Kriz D., Ramstrom O., Svensson A., Mosbach K. A biomimetic sensor based on a molecularly imprinted polymer as a recognition element combined with fiber-optic detection // Anal. Chem.-1995.-67, N 13.-P. 2142-2144.

170. Suarez-Rodriguez J. L., Diaz-Garcia M. E. Flavonol fluorescent flow-through sensing based on a molecular imprinted polymer // Anal. Chim. Acta.-2000.-405, N 1-2.-P. 67-76.

171. Kriz D., Mosbach K. Competitive amperometric morphine sensor based on an agarose immobilised molecularly imprinted polymer // Anal. Chim. Acta.-1995.-300, N 1-3.-P. 7175.

172. Haupt K., Mayes A. G., Mosbach K. Herbicide assay using an imprinted polymer-based system analogous to competitive fluoroimmunoassays // Anal. Chem.-1998.-70, N 18.P. 3936-3939.

173. Levi R., McNiven S., Piletsky S. A., Cheong S.-H., Yano K., Karube I. Optical detection of chloramphenicol using molecularly imprinted polymers // Anal. Chem.-1997.-69, N 11.P. 2017-2021.

174. Haupt K. Molecularly imprinted sorbent assays and the use of non-related probes // React. Funct. Polym.-1999.-41, N 1.P. 125-131.

175. Piletsky S. A., Terpetschnik E., Andersson H. S., Nicholls I. A., Wolfbeis $O$. S. Application of non-specific fluorescent dyes for monitoring enantio-selective ligand binding to molecularly imprinted polymers // Fresenius J. Anal. Chem.1999.-364, N 6.-P. 512-516.

176. Matsui J., Higashi M., Takeuchi T. Molecularly imprinted polymer as 9-ethyladenine receptor having a porphyrin-based recognition center // J. Amer. Chem. Soc.-2000.-122, N 21.P. 5218-5219.

177. Shughart E. L., Ahsan K., Detty M. R., Bright F. V. Site selectively templated and tagged xerogels for chemical sensors // Anal. Chem.-2006.-78, N 9.-P. 3165-3170.

178. Kubo H., Yoshioka N., Takeuchi T. Fluorescent imprinted polymers prepared with 2 -acrylamidoquinoline as a signaling monomer // Org. Lett.-2005.-7, N 3.-P. 359-362.

179. Manesiotis P., Hall A. J., Sellergren B. Improved imide receptors by imprinting using pyrimidine-based fluorescent reporter monomers // J. Org. Chem.-2005.-70, N 7.-P. 27292738.

180. Li J., Kendig C. E., Nesterov E. E. Chemosensory performance of molecularly imprinted fluorescent conjugated polymer materials // J. Amer. Chem. Soc.-2007.-129, N 51.P. 15911-15918.

181. Sergeyeva T. A., Piletsky S. A., Brovko A. A., Slinchenko E. A., Sergeeva L. M., Panasyuk T. L., E'lskaya A. V. Conductometric sensor for atrazine detection based on molecularly imprinted polymer membranes // Analyst.-1999.-124, N 3.P. 331-335.

182. Sergeyeva T. A., Piletsky S. A., Brovko A. A., Slinchenko E. A., Sergeeva L. M., E'lskaya A. V. Selective recognition of atrazine by molecularly imprinted polymer membranes. Development of conductometric sensor for herbicides detection // Anal. Chim. Acta.-1999.-392, N 2-3.-P. 105-111.

183. Yamazaki T., Meng Z., Mosbach K., Sode K. A Novel amperomet ric sensor for organophosphotriester insecticides detection employing catalytic polymer mimicking phosphotriesterase catalytic center // Electrochemistry.-2001.-69, N 12.-P. 969-972.

184. Hutchins R. S., Bachas L. G. Nitrate-selective electrode developed by electrochemically mediated imprinting/doping of polypyrrole // Anal. Chem.-1995.-67, N 10.-P. 1654-1660.

185. Andersson L. I., Miyabayashi A., O'Shannessy D. J., Mosbach $K$. Enantiomeric resolution of amino acid derivatives on molecularly imprinted polymers as monitored by potentiometric measurements // J. Chromatogr. A.-1990.-516, N 2.P. 323-331.

186. Hedborg E., Winquist F., Lundstrom I., Andersson L. I., Mosbach $K$. Some studies of molecularly-imprinted polymer membranes in combination with field-effect devices // Sensors and Actuators A.-1993.-37-38.-P. 796-799.

187. Piletsky S. A., Piletskaya E. V., Elgersma A. V., Yano K., Karube I., Parhometz Y. P., Elskaya A. V. Atrazine sensing by molecularly imprinted membranes // Biosensors and Bioelectronics.-1995.-10, N 9-10.-P. 959-964.

188. Panasyuk T., Mirsky V. M., Piletsky S. A., Wolfbeis O. S. Electropolymerized molecularly imprinted polymers as receptor layers in capacitive chemical sensors // Anal. Chem.-1999.71, N 20.-P. 4609-4613.

$$
\text { UDC } 577.1+573.6+543.393+543.556+004.942
$$

Received 24.03.09 